\title{
Troublesome Masculinities: Masculinity in Trouble
}

\author{
Alan Greig
}

\begin{abstract}
This article explores the notion of 'troublesome' masculinities that characterise much of the policy discourse and programme thinking on problems of young men and gender. It critiques the dimorphism that shapes this view of young men's gender trouble, and the 'culturalism' that constrains the perception of the troubled times in which many young men live. The article argues that young men can be enlisted in the feminist struggle to transform ideologies and institutions of male power, but only by troubling both the notions of masculinity that underpin them as well as the structural inequalities within which they are enmeshed.
\end{abstract}

An extraordinary growth in research and programming on masculinities continues to explore the ways in which to challenge male authority by redefining male identity. Given the long-standing and deeply entrenched patriarchal ideology that equates male identity with men's authority over women, this tension would appear to be a significant obstacle facing the momentum for change towards gender equality and men's part in it.

Much good work has been done to address this tension. There is a large and growing literature on masculinities work with men and boys that looks at the successes and challenges of this work in trying to engage men in the gender equality project. Evaluations of this work show promise in terms of its effectiveness in shifting patriarchal attitudes and practices. On this basis, there is now a growing interest in how to take this work 'to scale' through policy change. In both national and international fora, the challenges of engaging men in the public policy project of gender equality are being increasingly debated. In light of the tension described above, these challenges are frequently framed in terms of the policies that are needed to promote and secure a gender-equitable masculinity for men, a male identity founded not on male authority but on the vision and principles of gender equality. Within a broader understanding of the social construction of gender, as a set of meanings and practices that are performed individually and reproduced institutionally, attention is thus being given to that which helps to construct masculinity and turn boys into men. As an overview of gender issues facing young men in sub-Saharan Africa makes clear:

Peer and community norms are highly influential for young men who often feel the need to affirm their status and identity before their male peer group ... This means that gender work should include all those involved in the socialisation of young men - teachers, families, peer groups, community leaders, schools, the military, and the media, among others. (Barker and Ricardo 2006: 133)

The 'socialisation of young men' and the relationship between social norms and constructions of masculinity and femininity have become the focus of policy development in an increasing number of countries. Policy debate has centred on those social institutions that are held to exert the greatest influence on socialisation: the family (and in particular the role of the father within the family), the school, the workplace, the media and the organisation of violence (informally in gangs and formally within military and law enforcement institutions). Rather than review these debates, to whose voluminous literature an article of this nature cannot do justice, the article will instead 
examine the terms of the debates and the ways in which these terms speak to the trouble with masculinity.

The very concept of 'gender socialisation' has been taken to task for its deterministic and reductive rendering of the complex dynamics between social subject and social structure:

[T] he dominant way of thinking about men remains locked on the individual, particularly through the deployment of 'sex role and gender socialisation' theory - a mishmash of various theories and measures that clearly are in great need of revision and replacement ... The dilemma with role theory is that it regards male bodies as empty vessels that get filled up to become men.

(Dowsett 2005: 5)

It is true that many accounts of young men's gender troubles, for example their violent behaviour or sexual risk-taking, tend to characterise them as products of their masculine socialisation, rather than the result of choices that some young men make and other men don't. But in practice, most masculinities work with men and boys is about helping them make different choices and does not regard them as 'empty vessels' simply awaiting their socialisation. Rather, they are addressed as 'active participants in internalising, reframing and reproducing gender norms that are passed on to them from their social settings, their families and their peers' (Barker and Ricardo 2006: 192). However, this begs both theoretical and empirical questions as to how men and boys internalise, reframe and reproduce gender norms and the ways in which structural forces shape these processes. Looking at the lives of 'positive deviants' to explore the factors that appear to enable some men to resist harmful gender norms has provided some answers, yet these answers remain individually framed (Barker 2006a).

\section{Agency and structure}

A more complex portrayal of young men's identity formation in relation to the structural determinants of their lives was offered nearly 30 years ago in Willis's groundbreaking ethnography of a group of working-class teenage boys in an industrial town in the UK (Willis 1981). Not only did the study highlight the young men's active and self-conscious cultivation of a 'traditional' working-class masculinity; crucially, it highlighted the importance of class, and to a lesser extent race, in determining these young white men's forging of their gender identity. Recognising that their working-class origins severely limited their access to middle-class occupations led the young men to cultivate an oppositional masculinity that rejected the middle-class aspirational values of the school and identified with the ethos of the 'shop floor'. Their gender practice became a source of class dignity, which, in rejecting education, reproduced capitalist relations by ensuring that workingclass youths got working-class jobs.

The insights of Willis's working-class boys into the realities of their class position and prospects find an echo in an International Labour Organization (ILO) study of working-class youth in the favelas (shanty towns) of Rio de Janeiro, which found that 'for low-income youth (male and female), educational attainment does not provide the same returns in terms of income gains as it does for middle-income youth' (Barker 2006a: 124).

This view of the complex interplay between young men's agency and social structure in their identity formation reminds us that it is never just about gender. Masculinity and femininity are imbricated with multiple, interacting relations of power. This in turn suggests that an effective response to the troublesome masculinities of young men requires not merely a better gender analysis but an intersectional analysis of multiple axes of oppression. This would make clear that the growing concern in some societies about the poor educational performance of boys must be a concern with not only gender but also class and race. Boys from privileged social backgrounds, who benefit from class and ethnic advantage, do extremely well in schools and universities. Boys' difficulties in schools are concentrated among those from social backgrounds marked by poverty, ethnic or racial inequality, or social disruption (Arnot et al. 1999; Teese et al. 1997). Far from calling for a gender-specific pedagogy that purports to meet the neglected needs of boys, an intersectional analysis of boys and education emphasises the need for a pedagogy that builds a critical consciousness of privilege and oppression among both girls and boys and a public policy commitment to investing in the 
education of the socially marginalised with due attention to its gender dimensions.

\section{Masculinity and hegemony}

Young people's insights into the limits of social mobility can only have sharpened in the 30 years since Willis conducted his fieldwork. In most societies, inequalities have intensified and social stratification has rigidified, at the same time as rapid urbanisation and economic informalisation have destabilised patterns of settlement and production in unprecedented ways. That it is young men rather than young women who tend to act out their anger and ambition through violence and criminality should come as no surprise, given the social permission given men in most societies to occupy and act in the public sphere. Expectations of male privilege may only further fuel young men's resentment at the indignities and inequalities they face, a resentment most easily directed at those closest and subordinate to them, namely women.

This is in no way to excuse men's violence, or to claim that men's violence is confined to the socially marginalised. 'As feminist and human rights analyses emphasise, girls and women can be victimised by men regardless of economic circumstances' (Zierler and Krieger 1997: 419). Research on the links between violence and masculinity in India concluded that:

If violence is viewed as a resource, it may be particularly salient for those who either do not have resources (such as lower castes), are losing resources (upper castes in Tamil Nadu) or those who have historically perceived a lack of social power (as in the newly empowered dalits). (ICRW 2002: 69)

As the historical and anthropological record shows, violence is and has been central to the gender orders of most societies. But an intersectional analysis draws attention to the ways in which the violence that is based in gender also operates within a broader matrix of relations of power, as the 'natural' hierarchy of gender serves to naturalise social relations of domination and subordination. The violence that men enact against women is structured by the coercive logic with which power is institutionalised and exercised by political and economic elites. As has been noted in relation to south Asia:
State formation in each of the south Asian cases has been premised on political investments in forms of violence, and their intersection with the daily, economic violence of poverty and systemic disenfranchisement. The state in south Asia emerges quite literally as the primary regulator of the means of violence. Its investment in the mechanism and language of war, in structures of inequality, in the glorification of military cultures, and nuclearisation only reinforces violence, and gendered violence in particular.

(Banerjee et al. 2004: 127)

If, as one overview of young men and the construction of masculinity in sub-Saharan Africa notes, 'too many young men are socialised into versions of manhood that encourage sexual aggression toward girls' (Barker and Ricardo 2006: 167), then it is important to understand the political contexts for this cultural construction. Recent work on the connections between gender and militarism and conflict is useful in this regard.

The study of gendered violence, we propose, should operate not just as short-hand for understanding violence on and against women, but also as an analytical category that is equally attentive to the ways in which normative ideas of masculinity and heterosexuality are disseminated amidst a pervasive context of militarism.

(Banerjee et al. 2004: 133)

Studies by Enloe (2000) among others have emphasised the work that states and military forces invest in constructing masculinities and femininities that mobilise men to fight and women to support men's fighting. Far from being innately violent, men are often reluctant to participate in military action (Blagojevic 1999). Ideas about and images of masculinity have been used, in many different places and times, to militarise these reluctant men.

Not only is masculinity used to mobilise men to fight, but anxiety over the violence of troublesome young men is used to re-secure established hierarchies. Taking hegemony to mean the capacity of dominant classes to persuade subordinate ones to accept, adopt and internalise their values and norms, the social history of moral panics reveals that this capacity 
has relied in part on the exploitation of social anxieties about the criminality and disorderly behaviour of young males, especially during times of intensified societal change (Pearson 1983). This is evident in the fears being generated around the 'youth bulge' thesis, 'personified as a discontented, angry young man, almost always a person of colour', who resides in huge numbers in Africa, the Middle East, and parts of Asia and Latin America and forms an 'unpredictable, out-of-control force' (Hendrixson 2003: 8, quoted in Sommers 2006: 140). In the words of a former Chairman of the US National Intelligence Council, this presence of large numbers of male youth in 'overcrowded' urban settings 'is likely to perpetuate the cycle of political instability, ethnic wars, revolutions, and anti-government activities that already affects many countries' (Helgerson 2002: 3, quoted in Sommers 2006: 139).

Noting that the thesis is particularly being applied to the rapidly expanding cities of subSaharan Africa, Sommers (2006: 139) reminds us that while the thesis 'purports to be scientific and predictive, it is frequently hammered home by members of the US security community'. It is clear that there can be an association between young men's violence and social instability. As Connell (2008: 11) notes, unemployed young men in the city of Algiers "came to be known as hittistes - "those who prop up the wall." In the growing conflict of the early 1990s they were a crucial source of recruits for the extremely violent urban wing of the Islamist rising in Algeria.' With regard to young men's involvement in the Rwandan genocide, Sommers notes that 'a life of crushing entrapment and frustration for the vast majority of Rwandans' (2006: 144) made 'poor, unemployed male youth easy pickings for those organizing the genocide' (ibid.: 146).

The point is that the troublesome masculinities of young men have long been instrumentalised in the service of economic and political interests, both as a source of fear to secure consent and as a tool of power to secure control. Working with young men to understand the ways in which their masculinities are being mobilised in the service of hegemony is an important piece of political consciousness-raising that is rarely found in programmes working with them on gender and violence. At the same time, there is a need to address not just young men's gender identities and practices but also the social and economic conditions of their lives. As Sommers concludes:

$[\mathrm{T}]$ he answer to the youth challenge is not to further marginalize or paint male youth as fearsome security threats. That can only inspire increased alienation and a sense of being cornered. It is, in fact, quite the opposite: unemployed, undereducated young men require positive engagement, appropriate empowerment, and participatory financial and program support. (Sommers 2006: 154)

\section{Managing the crisis}

That this spectre of violent urban male youth is being aroused at this time of profound social change in many parts of the world is unsurprising; their troublesome masculinities are being invoked to manage a deeper crisis. As Segal (1990: 264) writes: 'There was a time, it seems to me, when feminists would not so readily have lost sight of the significance of class oppression for the sake of identifying a universal male beastliness.' Neoliberal globalisation, as Connell notes, has in many ways exacerbated such class oppression:

With the destruction of welfare states and the development strategy of import replacement industrialization in the global periphery, there has been a massive rise in economic insecurity for working-class families, and particularly high rates of unemployment for working-class youth. (Connell 2008: 11)

For some, the language of crisis surrounding young men and their violent masculinity is being used to pathologise and pacify anger about and resistance to class oppression:

Masculinity theories do appear to be telling us something about a loss of power that matches their real condition. But it is wrong to see this loss of power as a loss in relation to women. Rather it is in relation to capital that men and women alike have lost authority ... The crisis is not one of masculinity, but one of the working class. (Heartfield 2002)

Yet, there are gender dimensions to the crises produced by neoliberal economic policies. Research is revealing the impact of increasing male unemployment on young men's gender 
identity and gender authority. A recent overview of young men and the construction of masculinity in sub-Saharan Africa has concluded that the 'main social requirement for achieving manhood ... - for being a man - is attaining some level of financial independence, employment, or income, and subsequently starting a family' (Barker and Ricardo 2006: 161) but that this pathway to manhood is increasingly being blocked for many young men by prevailing economic conditions and political instability. More broadly, as Connell (2008: 11) states: 'In third-world cities there has been a de-institutionalisation of economic life that has left very large numbers of young men in precarious conditions.' At the same time, the entry of young unmarried women into paid work has afforded greater economic and social autonomy for many (Kabeer 2007) with important implications for changes in gender relations and ideologies within the household and the larger society, and for women's gender consciousness and activism (Safa 1996).

But the degree of change in the prevailing gender order should not be overstated. 'Much of the increase in female labor-force participation in developing countries has occurred in the informal sectors of the economy,' as Moghadam (1999: 374) emphasises. Rising unemployment and reduced wages for men in a given household has increased the 'double shift' of women's productive and reproductive labour. 'In many ways, the women of the working class and urban poor have been the "shock absorbers" of neoliberal economic policies,' Moghadam has concluded (1999: 377). Indeed, neoliberalism's impact on women through its undermining of the welfare state, public education, health service delivery and public sector employment make it one of the greatest determinants of continuing gender inequality. 'Much more important for the defence of gender inequality are movements in which men's interests are a side effect - nationalist, ethnic, religious, and economic movements. Of these, the most influential on a world scale is contemporary neoliberalism', Connell (2005: 1815) reminds us.

This neoliberal onslaught is rarely identified as a focus of and foundation for masculinities work with young men, however. In framing the 'precarious conditions' of young men's lives as a problem of gender identity, of ways of becoming and being a man, such work often neglects the realities of intersecting oppressions that constitute these conditions. As a result, the broader implications for policy change are not drawn and the nature of the struggles to secure such policies is not clarified. In focusing on gender identity, masculinities work can distract attention from the shared class interest in common struggle that young women and men in communities suffering the effects of neoliberal economic policy have against the agents of such policy. In so doing, the opportunity to build solidarity between young women and men around gender equity within a broader social justice agenda can be lost.

\section{Securing masculinity?}

The problems with this insistence on working on the masculine identity of young men as a way to promote gender equity are apparent in the burgeoning debates over fatherhood. Such debates feature prominently in discourses on the socialisation of young men and policy responses to their troublesome masculinities. Such debates and discourses are fuelled by emerging evidence that fatherhood is good for gender equality, though whether it is more fatherhood or different fatherhood is sometimes less clear. Barker (2006b: 53) notes that 'there is some empirical evidence from North America and Western Europe that positive father involvement increases the chance that sons will be more genderequitable and more nurturing as fathers, and that daughters will have more flexible views about gender.' Studies show that men involved in the nurturing of young children are much less likely later on to engage in violence against their female partners, with important consequences for children and their mothers (Plantin et al. 2003). Barker (2006b: 54) reports that a 'qualitative study of low-income young men in Brazil found that young men who are gender-equitable had a father or other male figure who demonstrated these roles while they were children themselves.'

It is this recognition that has driven much of the policy effort to increase men's involvement in fatherhood. Paternity-establishment legislation, for example in Costa Rica and Chile, appears to have been effective not only in meeting the goal of establishing paternity in individual cases but also in motivating and pressuring men to fulfil their parental responsibilities, though it is less clear if this extends beyond financial responsibilities to include a greater emotional engagement. Evidence from the European Union 
suggests that policy regimes regarding parental leave have a direct impact on fathers' involvement in caring for children and that, in general, men in countries with more fatherfriendly policy regimes do spend more time caring for their children (Smith 2001: 26). A national law is currently being debated in Brazil that would make 30 days of paternal leave available for all fathers of newborns.

Progress is limited however. A study of parental leave in Europe (Council of Europe 2005: 41) concluded that 'all the national data point to the continuation, and at best only partial weakening, of women's predominance as those availing of parental leave and any associated benefits.' Data suggest that worldwide fathers contribute far less time than women to direct childcare, although there is tremendous variation across countries and among men. Studies from a range of settings find that fathers contribute about one-third to one-fourth of the time that mothers do to direct childcare (Miedzian 1991). For many of these men, and the mothers of their children, parental leave policy is an irrelevance given their employment status and economic circumstances.

In response, the Council of Europe report (2005: 42) recommends that to "ensure a more equitable distribution of caring means that "fatherhood" has to be seen as "manly" and that parental leave can contribute to a win-win outcome for fathers, mothers and children'. Yet, this normative equating of fatherhood with manliness is exactly what discourses of fatherhood and gender equity argue against; 'any discussion of what it means for men to help conceive and parent children that does not include a serious redefinition of what it means to be a man is an impoverished one by definition' (pers. comm. Richard Newman 2003). In doing so, they are countering the work of Chodorow (1978) and other psychoanalytically informed accounts of absent fatherhood, and thus deficient manliness, being at the root of the troubles that boys experience in their 'normal' development into men.

Such accounts, with added racism and class condescension, can be seen lurking in the pathologising of single, female-parent families, most notoriously in the case of the 'Moynihan report' of 1965 (Reed 1999), which blamed the 'rioting' of young black men in the urban unrest of the late $1960 \mathrm{~s}$ in the USA on the 'dysfunctional' black family and its absence of fathers. Even without the explicit anti-feminism of the Fathers' Rights movement, it is easy to see how the push for fatherhood policies can mesh with the patriarchal conviction that boys need fathers in order to become proper men. This is especially true in the (many) societies with entrenched patriarchal histories and cultures, whose profound transitions in response to the impacts of neoliberalism described above, are being understood, and managed, in terms of a 'crisis' of masculinity.

Countering this masculinising of fatherhood implies a need to focus on men's engagement in equitable parenting rather than on fatherhood per se and the many ways in which men can be parents to as well as parents of children. Significantly, it also requires that parenting policy be grounded in a conversation about the political economy of productive and reproductive labour. As the Council of Europe (2005: 42) report urges: 'In order to avoid parental leave becoming a ghetto for women with lower educational attainment, hence lower income and occupational status, the debate has to extend to the paid/unpaid division of labour in society as a whole.'

There is also a need to recognise the diversity of family formations, and challenge the heteronormativity of public policy that presumes the heterosexual union to be the foundation of 'normal' families and thus healthy child development, for both boys and girls. Indeed, this is a deeper challenge for the 'men and masculinities' field as a whole, whose heteronormative conviction that men need 'their' masculinity, albeit a gender equitable one, is part of the problem rather than the solution. In trying to recuperate a non-oppressive masculinity for men, the field persists in aligning masculinity with men (and by implication femininity with women) and, in so doing, risks being complicit with the fear and refusal of the feminine that underlies misogyny. Rather, the task must be to 'drive a wedge in, early and often and if possible conclusively, between the two topics, masculinity and men, whose relation to one another it is so difficult not to presume' (Kosofsky-Sedgwick 1995: 12).

This is no easy task, especially in view of the profound societal transitions described above. 'Traditional' gender orders may not only be seen 
as a bulwark against the encroachments of globalisation, by both women and men alike, but they are also a source of power for men in an otherwise disempowering world. Yet, troubling the notion of masculinity is a critical component of the work that is needed with young people, if they are to grow up in a world of greater gender equity. In terms of policy development on the masculinities of young men, this calls for much greater attention to be given to non-normative gender and sexual practices and identities as

\section{References}

Arnot, Madeleine; David, Miriam and Weiner, Gaby (1999) Closing the Gender Gap: Post-war Education and Social Change, Cambridge: Polity Press

Banerjee, Sukanya; Chatterji, Angana; Chaudry, Lubna Nazir; Desai, Manali; Toor, Saadia and Visweswaran, Kamala (2004) 'Engendering Violence: Boundaries, Histories, and the Everyday', Cultural Dynamics 16.2/3: 125-39

Barker, Gary (2006a) 'Growing up Poor and Male in the Americas: Reflections from Research and Practice with Young Men in Low-Income Communities in Rio de Janeiro', in Ian Bannon and Maria C. Correia (eds), The Other Half of Gender, Washington DC: World Bank

Barker, Gary (2006b) 'Men's Participation as Fathers in Latin America and the Caribbean', in Ian Bannon and Maria C. Correia (eds), The Other Half of Gender, Washington DC: World Bank

Barker, Gary and Ricardo, Christine (2006) 'Young Men and the Construction of Masculinity in Sub-Saharan Africa: Implications for HIV/AIDS, Conflict, and Violence', in Ian Bannon and Maria C. Correia (eds), The Other Half of Gender, Washington DG: World Bank

Blagojevic, Marina (1999) 'Gender and Survival: Serbia in the 1990s', online article available from the author at marinab@zeus.colbud.hu

Chodorow, Nancy (1978) The Reproduction of Mothering: Psychoanalysis and the Sociology of Gender, Berkeley and Los Angeles: University of California Press

Connell, Raewyn (2008) 'A Thousand Miles from Kind: Masculinities and Modern Institutions', keynote address for 16th annual conference of American Men's Studies Association, Masculinities and Institutions: Mapping the Connections, Wake Forest University, Winston-Salem, 4-6 April well as to advocacy efforts to secure legal rights and protections for women and men within lesbian, gay, bisexual, transgender and intersex communities. For young men as a whole, it implies a need to create spaces within the institutions of socialisation, notably schools and youth centres, to discuss not only masculinity and patriarchy, but also femininity, misogyny and homophobia. In this end, this work is not about securing a new masculinity for men but dignity and self-determination for people of all genders.

Connell, Raewyn (2005) 'Change Among the Gatekeepers: Men, Masculinities, and Gender Equality in the Global Arena', Signs: Journal of Women in Culture and Society 30.3: 1801-25

Council of Europe (2005) Parental Leave in Council of Europe Member States, Strasbourg: Equality Division, Directorate General of Human Rights, Council of Europe

Dowsett, Gary (2005) 'Moving Masculinities and Social Change: Why Do Men Matter?', a lecture presented at the Moving Masculinities: Crossing Regional and Historical Borders international conference, Gender Relations Centre, Australian National University, Canberra, 29 November to 2 December

Enloe, Cynthia (2000) Maneuvers: The International Politics of Militarizing Women's Lives, Berkeley and Los Angeles: University of California Press

Heartfield, J. (2002) 'There is No Masculinity Crisis', Genders 35

Helgerson, John L. (2002) 'The National Security Implications of Global Demographic Change', 30 April, www.au.af.mil/au/awc/ awcgate/cia/helgerson2.htm (accessed 17 October 2008)

Hendrixson, Anne (2003) 'The Youth Bulge: Defining the Next Generation of Young Men as a Threat to the Future', Different Takes 19, Amherst: Population and Development Program at Hampshire College

ICRW (International Center for Research on Women) (2002) Men, Masculinity and Domestic Violence in India: Summary Report of Four Studies, Paper No. 4 on Domestic Violence in India: Exploring Strategies, Promoting Dialogue, Washington DG: ICRW

Kabeer, Naila (2007) Marriage, Motherhood and Masculinity in the Global Economy: Reconfigurations of Personal and Economic Life, IDS Working Paper 290, Brighton: IDS 
Kosofsky-Sedgwick, Eve (1995) 'Gosh, Boy George, You Must Be Awfully Secure in Your Masculinity', in M. Berger, B. Wallis and S. Watson (eds), Constructing Masculinity, New York: Routledge

Miedzian, Myriam (1991) Boys Will Be Boys: Breaking the Link Between Masculinity and Violence, New York: Doubleday

Moghadam, Valentine M. (1999) 'Gender and Globalization', Journal of World-Systems Research 5.2: 367-88

Pearson, Geoffrey (1983) Hooligan: A History of Respectable Fears, Basingstoke: Macmillan

Plantin, Lars; Mansson, Sven-Axel and Kearney, Jeremy (2003) 'Talking and Doing Fatherhood: On Fatherhood and Masculinity in Sweden and Britain', Fathering 3.26

Reed, Adolph Jnr (1999) Stirrings in the Jug: Black Politics in the Post-Segregation Era, Minneapolis, MN: University of Minnesota Press

Safa, Helen (1996) 'Gender Inequality and Women's Wage Labor: A Theoretical and Empirical Analysis' in Valentine M. Moghadam (ed.), Patriarchy and Development, Oxford: Clarendon Press

Segal, Lynne (1990) Slow Motion: Changing Masculinities, Changing Men, London: Virago
Smith, Alison J. (2001) 'Parental Leave: Supporting Male Parenting? A Study Using Longitudinal Data of Policy Variation Across the European Union', paper given at the EURESCO Second Demographic Transition in Europe, Bad Herrenalb, Germany, 23-28 June: 4-5

Sommers, Marc (2006) 'Fearing Africa's Young Men: Male Youth, Conflict, Urbanization, and the Case of Rwanda', in Ian Bannon and Maria C. Correia (eds), The Other Half of Gender, Washington DC: World Bank

Teese, R.; Davis, M.; Charlton, M. and Polesel, J. (1997) 'Who Wins at School: Which Boys, Which Girls?', in J. Kenway (ed.), Will Boys be Boys?' Boys' Education in the Context of Gender Reform, Canberra: Australian Curriculum Studies Association

Willis, Paul E. (1981) Learning To Labour: How Working Class Kids Get Working Class Jobs, New York: Columbia University Press

Zierler, Sally and Krieger, Nancy (1997) 'Reframing Women's Risk: Social Inequalities and HIV Infection', Annual Review of Public Health 18: 401-36 